\title{
A New Approach to Measuring Work-Related Well-Being
}

\author{
Reetta Orsila \\ Tampere School of Public Health, University of Tampere, Tampere, Finland
}

Tiina Luukkaala

Tampere School of Public Health, University of Tampere, Tampere, Finland

Science Center, Pirkanmaa Hospital District, Tampere, Finland

Marja-Liisa Manka

Tampere School of Management, University of Tampere, Tampere, Finland

\section{Clas-Håkan Nygård}

Tampere School of Public Health, University of Tampere, Tampere, Finland

The main aim of this study was to develop a short questionnaire to assess work-related well-being from the organizational behaviour perspective. The short well-being questionnaire enables measuring longitudinal work-related well-being. Work-related well-being was assessed with a 147-item questionnaire covering both organizational and intrinsic factors of work-related well-being. The questionnaire consisted of 27 categories. The respondents were 114 women (65\%) and 62 men (35\%), mean age 39.2 years, in various occupations. From the extensive questionnaire a shorter questionnaire with 33 items was developed by principal component analysis. The Kaiser-Meyer-Olkin measure to test the sampling adequacy of 27 factor solutions varied from .62 to .91 and Cronbach's a was .74-.94. Most $\kappa$ values of the shorter questionnaire were .50-.94 $(\mathrm{p}<.001)$. The reliability of the short version was comparable to that of the original questionnaire. The short one could also be suitable for Internet and mobile questionnaire applications.

$$
\text { work-related well-being organizational climate intrinsic factors }
$$

\section{INTRODUCTION}

Good work from the organizational behaviour perspective is nowadays an ample research area. Work-related well-being has been studied since the 1930s [1]. Although a relationship between good work and work-related well-being has long been recognized [2], employees in similar environments react differently [3]. There are ample definitions of work-related well-being depending on the discipline [4]. The phenomenon of work-related well-being is depicted in various concepts as well-being at work, work engagement and job satisfaction [5]. Work engagement is, e.g., a positive, motivational reaction towards the job that is characterized by vigour, dedication and absorption [6].

At workplaces considerations are often restricted to only one dimension of work-related well-being, such as job satisfaction, which is an important

Correspondence and requests for offprints should be sent to Reetta Orsila, Tampere School of Public Health, University of Tampere, Tampere, Finland. E-mail: <reetta.orsila@uta.fi>. 
dimension of employee well-being [7]. For example, in economics work-related wellbeing is equated with job satisfaction, but in health sciences work job satisfaction is only one dimension of work-related well-being. Workrelated well-being is typically studied from the perspectives of work stress seeing the workplace as a static, not as a changing place [8]. Both organizational factors such as organizational climate and intrinsic factors like work ability, experiences of work flow, and personality, including optimism and self-confidence affect work-related well-being. Organizational climate is closely related to work-related well-being [9]. Recent studies have demonstrated that personal resources such as optimism are related to work engagement [10]. Work engagement is an emerging psychological concept [12].

The relation between personal and job resources is reciprocal [10]. Organizations which find their personnel a valuable resource are interested in the good health and wellbeing of the employees in addition to their work performance [13]. Crucial concepts of organizational factors like organizational climate include autonomy, clarity of organizational goals, efficiency, effort, formalization, innovation and flexibility, integration, outward focus, participation, performance feedback, pressure to produce, quality, reflexivity, supervisory support, tradition, training and welfare [14, 15]. Work ability, which consists of work demands and individual resources, is a key concept of employee well-being [16]. Individual factors of work-related well-being include mainly health [17], work ability [18], perceived stress [19], mental well-being [20], job satisfaction [21], work flow [22], personality [23], self-esteem [24] and optimism [25]. According to Bakker and Schaufeli, employees who experience work engagement are mentally and physically healthier [26].

Employee well-being can be approached from both positive and negative perspectives. Work-related well-being is commonly discussed negatively in terms of symptoms, not preventively, which is a key principle developing work-related well-being [27]. Recently work- related well-being has largely been defined through negative emotions [29] like burnout, dissatisfaction and anxiety instead of positive emotions like work engagement. Burnout is a traditional, negative approach to well-being, while work engagement represents positive psychology [29]. Work-related well-being research [30] is more and more based on positive psychology studying employee well-being positively, e.g., with the Job Demands-Resources model (JD-R) [31].

JD-R, in which work characteristics are divided into demands and resources, is one of the most common models for measuring work engagement [32]. Job resources refer to organizational, physical, psychological and social aspects of the job that are functional in achieving work-related goals, reducing demands, stimulating personal growth and development [12]. In addition, job resources affect job performance, decrease the negative consequences of work demands and promote learning at the workplace [12, 32]. In Manka's study personal growth motivation was shown to consist of the organization, group work, work and the individual [33]. The climate for personal growth at the organization was based on supervisory support, development opportunities and dignity of the work, communality and team spirit [33]. Job demands are psychological, physical, social or organizational characteristics of work requiring physical and mental effort from the employee.

Other measures in a positive approach are happiness [34], personality [34], optimism [35] and eustress [36]. The positive work stress approach should also be studied more [37]. In general, work-related well-being is a subjective experience of an employee, which is influenced by work, an individual's life and life history [38]. In short, employee work-related well-being can be understood as emotional, psychological and physical well-being and health behaviour [39].

Individuals react differently to stressors during organizational changes [40]. The outcomes of organizational and individual well-being are connected: a good organizational climate offers good prospects for work flow like absorption, 
work enjoyment, intrinsic motivation and lifelong learning. Supervisory support, clarity of organizational goals, innovation and flexibility, and performance feedback are also necessary [15]. Empirical studies have shown that good work offers the opportunity to derive motivation from the work itself. Job resources are autonomy, social support, performance feedback and opportunities to learn. These resources are also significant because of their motivational qualities [41].

Moreover, individuals interpret the workplace in light of their own individual experiences. Subjective well-being consists of coping with work, growth motivation and competence [42]. Older employees report better work-related wellbeing than younger employees [4]. Younger employees suffer from stress more than older employees [43]. On the other hand, there are no significant differences between young and old employees nor between men and women [44]. This refers to the impact of organizational climate and intrinsic factors like work ability, work flow and personality on the understanding of work-related well-being.

Safety and health at work are a basis for workrelated well-being. Changes in organizational structures and work habits emphasize the need to research work-related well-being. The Finnish Occupational Safety Act (738/2002) stresses the obligation of an employee regarding recognising risk identification and assessment at work [45]. The main ways of measuring are questionnaires, interviews and psychophysiological measurements [4, 14, 15]. Research in the field of work-related well-being is typically focused on narrow items rather than overviews of work-related well-being [2] as a subjective, work-based experience. According to Mäkitalo, most previous studies focused only on a few resources measuring work-related wellbeing [46]. Because of this, work-related wellbeing studies should preferably investigate how various types of job and personal resources relate to work engagement [10]. Mobile web-based questionnaires make it easier to perform reliable field test concerning work well-being [11].

\section{Objectives}

The main aim of this study was to develop a short version the work-related well-being questionnaire based on earlier studies according to a literature review to assess in a positive way work-related well-being among volunteers. A limitation of much of the existing research on perceived work-related well-being is that studies have tended to focus on only a few variables of work-related well-being, such as work satisfaction. The subjects answered the questionnaire and repeated the questionnaire again in 3 weeks to test the repeatability of the questionnaire.

\section{MATERIAL AND METHODS}

To identify pertinent studies for the comprehensive questionnaire we focused on key dimensions of work-related well-being: organizational climate and individual factors. We searched in MEDLINE and CINAHL $^{1}$ for relevant articles published in English in 1982-2008. Used keywords were psychological well-being and wellness at work, well-being at work, workrelated well-being and occupational health. We also reviewed reference lists in relevant published articles and books.

The work-related well-being questionnaire consisted of two parts. The subjects reported work-related well-being including both organizational climate and individual factors in the 147item questionnaire. The organizational climate measure $[14,15]$ consisted of 82 items in 17 categories. The categories of organizational climate items were autonomy (5 items), clarity of organizational goals (5 items), efficiency (4 items), effort (5 items), formalization (5 items), innovation and flexibility (6 items), integration (5 items), outward focus (5 items), participation (6 items), performance feedback ( 5 items), pressure to produce (5 items), quality (4 items), reflexivity (5 items), supervisory support (5 items), tradition (4 items), training (4 items) and welfare (4 items). Organizational

\footnotetext{
1 http://www.ebscohost.com/cinahl/
} 
climate was measured on a scale from 1 (definitely false) to 4 (definitely true).

The intrinsic work-related well-being items consisted of 65 items in 10 categories. Health was measured with three items on a scale from 0 (poor) to 10 (excellent) [17]. Stress was measured with a question by Elo [13]. The scale was from 0 (no stress at all) to 10 (lots of stress). Mental and physical work ability was measured with a short version of the work ability index with 2 items [18]. The scale was from 0 (poor) to 10 (excellent). Mental wellbeing was measured with 12 items from the general health questionnaire [20]. The scale was from 0 (better than usual) to 3 (much more than usual). Work satisfaction was measured with a 2-item, 5-point scale based on Hackman's Work Diagnostic Survey [21]. The items measured general work satisfaction on a scale from 0 (very unsatisfied) to 10 (very satisfied). Flow at work was assessed with the WOrk-reLated (WOLF) Flow scale [22]. The WOLF includes 14 items measuring absorption (4 items), work enjoyment (4 items) and intrinsic work motivation (6 items). The participants were asked to indicate how often they had each of the experiences during the preceding week (0-never, 7-always). Personality was measured with Ojanen's questionnaire with 9 items [23]. The scale was from 0 (very little) to 10 (exceedingly). Self-confidence was measured with the self-image questionnaire by Rosenberg with 10 items using a scale from 1 (totally disagree) to 5 (totally agree) [24]. Optimism was measured with Scheier's questionnaire with 12 items [25]. The scale was from 0 (strongly disagree) to 4 (strongly disagree).

In the present study, 176 volunteer employees (62 males and 114 females) responded to a comprehensive work-related well-being questionnaire. The response rate was 55\% (176/320). Participants were employees from the public and private sector in Tampere region. Participants were informed about the purpose of the study and asked to participate voluntarily. The questionnaire and instructions were provided to each employee individually. The subjects had the option to respond on paper or electronically to the web-based questionnaire. The participants worked as managers, researchers, teachers, registered nurses, academic assistants and engineers. Their mean age was 39.2 years $(S D$ 11.6, range 21-65, interquartile range 28-48). Most (72.4\%) had higher academic education and were employed as higher white-collar workers. Most $(67.7 \%)$ were employed by the state. Most employees $(84.1 \%)$ were not supervisors and were on fixed-term contracts $(56.6 \%)$. In addition, repeatability of the new questionnaire was measured among 19 volunteers from the sample.

Tables 1-27 show the exact questions of each item. Due to the skewed distributions, values of continuous variables were expressed as medians and interquartile ranges. The shorter questionnaire was constructed by Cronbach's $\alpha$ and principal component analysis, in which the interpretation of the factors was based on loadings over .4. Factors with eigenvalues greater than 1.0 were extracted for inclusion in the analysis. The number of those factors formed the number of the questions for the new questionnaire. Statistical analyses were elicited with SPSS for Windows version 15.0. In addition the agreement of two repeated work-related wellbeing questionnaires $(n=19)$ was tested with the weighted $\kappa$ with $95 \%$ confidence intervals and analysed with StatXact-4 version 4.0.1. 
TABLE 1. Median (Mdn) and Interquartile Range (IQR) of Items and Their Loadings and Communality in Principal Component Analysis One-Factor Solution $(n=176)$ of Autonomy

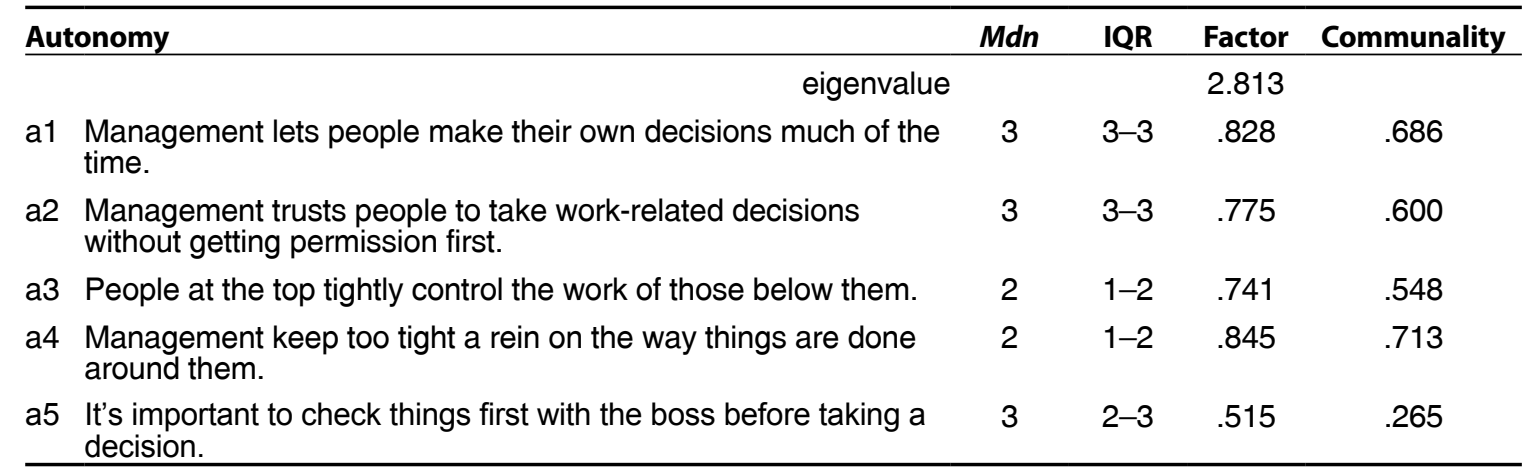

TABLE 2. Median (Mdn) and Interquartile Range (IQR) of Items and Their Loadings and Communality in Principal Component Analysis One-Factor Solution $(n=176)$ of Organizational Goals

\begin{tabular}{|c|c|c|c|c|c|}
\hline \multicolumn{2}{|r|}{ Clarity of Organizational Goals } & Mdn & IQR & Factor & Communality \\
\hline \multicolumn{3}{|c|}{ eigenvalue } & & 2.879 & \\
\hline $\mathrm{c6}$ & $\begin{array}{l}\text { People have a good understanding of what the organization } \\
\text { is trying to do. }\end{array}$ & 3 & $3-4$ & .792 & .628 \\
\hline c7 & $\begin{array}{l}\text { The future direction of the company is clearly communicated } \\
\text { to everyone. }\end{array}$ & 3 & $2-3$ & .726 & .528 \\
\hline c8 & People are not clear about the aims of the company. & 2 & $2-2.75$ & .727 & .529 \\
\hline c9 & $\begin{array}{l}\text { Everyone who works here is well aware of the long term } \\
\text { plans and direction of this company. }\end{array}$ & 3 & $2-3$ & .783 & .614 \\
\hline $\mathrm{c} 10$ & There is a strong sense of where the company is going. & 3 & $2-3$ & .762 & .581 \\
\hline
\end{tabular}

TABLE 3. Median (Mdn) and Interquartile Range (IQR) of Items and Their Loadings and Communality in Principal Component Analysis One-Factor Solution $(n=176)$ of Efficiency

\begin{tabular}{lcccc}
\hline Efficiency & Mdn & IQR & Factor & Communality \\
\hline eigenvalue & & & 2.701 & \\
e11 Time and money could be saved if work were better organised. & 3 & $2-3$ & .867 & .752 \\
e12 Things could be done much more efficiently if people stopped & 3 & $2-3$ & .765 & .586 \\
to think. & & & & .630 \\
$\begin{array}{l}\text { e13 Poor scheduling and planning often result in targets not being } \\
\text { met. }\end{array}$ & 2 & $2-3$ & .793 & .630 \\
$\begin{array}{l}\text { e14 Productivity could be improved if jobs were organised and } \\
\text { planned better. }\end{array}$ & 3 & $2-3$ & .857 & .734 \\
\hline
\end{tabular}

TABLE 4. Median (Mdn) and Interquartile Range (IQR) of Items and Their Loadings and Communality in Principal Component Analysis One-Factor Solution $(n=176)$ of Effort

\begin{tabular}{|c|c|c|c|c|}
\hline Effort & Mdn & IQR & Factor & Communality \\
\hline eigenvalue & & & 2.674 & \\
\hline $\begin{array}{l}\text { e15 People have always wanted to perform to the best of their } \\
\text { ability. }\end{array}$ & 3 & $3-3$ & .693 & .480 \\
\hline e16 People are enthusiastic about their work. & 3 & $3-3$ & .754 & .568 \\
\hline e17 People here get by with doing as little as possible. & 1 & $1-2$ & .660 & .435 \\
\hline e18 People are prepared to make a special effort to do a good job. & 3 & $3-3$ & .842 & .709 \\
\hline $\begin{array}{l}\text { e19 People here do not put more effort into their work than they } \\
\text { have to. }\end{array}$ & 2 & $1-2$ & .694 & .481 \\
\hline
\end{tabular}


TABLE 5. Median (Mdn) and Interquartile Range (IQR) of Items and Their Loadings and Communality in Principal Component Analysis One-Factor Solution $(n=176)$ of Formalization

\begin{tabular}{lcccc}
\hline Formalization & Mdn & IQR & Factor & Communality \\
\hline f20 It is considered extremely important here to follow the rules. & 3 & $2-3$ & .772 & .595 \\
f21 People can ignore formal procedures and rules if it helps get the & 2.5 & $2-3$ & .775 & .601 \\
job done. & & & & \\
f22 Everything has to be done by the rules. & 2 & $2-3$ & .792 & .627 \\
f23 It's not necessary to follow procedures to the letter around here. & 3 & $2-3$ & .762 & .580 \\
f24 Nobody gets too upset if people break the rules around here. & 2 & $1-2$ & .648 & .419 \\
\hline
\end{tabular}

TABLE 6. Median (Mdn) and Interquartile Range (IQR) of Items and Their Loadings and Communality in Principal Component Analysis One-Factor Solution $(n=176)$ of Innovation and Flexibility

\begin{tabular}{|c|c|c|c|c|}
\hline Innovation and Flexibility & Mdn & IQR & Factor & Communality \\
\hline eigenvalue & & & 3.647 & \\
\hline i25 New ideas are readily accepted here. & 3 & $2-3$ & .773 & .597 \\
\hline $\begin{array}{l}\text { i26 The organization is quick to respond when changes need to be } \\
\text { made. }\end{array}$ & 2 & $2-3$ & .826 & .682 \\
\hline $\begin{array}{l}\text { i27 Management here are quick to spot the need to do things } \\
\text { differently. }\end{array}$ & 2 & $2-3$ & .693 & .481 \\
\hline $\begin{array}{l}\text { i28 This organization is very flexible; it can quickly change } \\
\text { procedures to meet new conditions and solve problems as they } \\
\text { arise. }\end{array}$ & 3 & $2-3$ & .818 & .669 \\
\hline i29 Assistance in developing new ideas is readily available. & 3 & $2-3$ & .791 & .625 \\
\hline $\begin{array}{l}\text { i30 People in this organization are always searching for new ways } \\
\text { of looking at problems. }\end{array}$ & 3 & $2-3$ & .770 & .594 \\
\hline
\end{tabular}

TABLE 7. Median (Mdn) and Interquartile Range (IQR) of Items and Their Loadings and Communality in Principal Component Analysis One-Factor Solution $(n=176)$ of Integration

\begin{tabular}{lcccc}
\hline Integration & Mdn & IQR & Factor & Communality \\
\hline & eigenvalue & & 2.822 \\
i31 People are suspicious of other departments. & 2 & $2-3$ & .755 & .569 \\
i32 There is very little conflict between departments here. & 3 & $2-3$ & .742 & .551 \\
i33 People are prepared to share information with each other. & 3 & $2-3$ & .781 & .609 \\
i34 Collaboration between departments is very effective. & 2 & $2-3$ & .703 & .495 \\
i35 There is very little respect between some of the departments & 2 & $2-3$ & .773 & .598 \\
& & & & \\
here.
\end{tabular}

TABLE 8. Median (Mdn) and Interquartile Range (IQR) of Items and Their Loadings and Communality in Principal Component Analysis One-Factor Solution $(n=176)$ of Outward Focus

\begin{tabular}{|c|c|c|c|c|}
\hline Outward Focus & Mdn & IQR & Factor & Communality \\
\hline eigenvalue & & & 3.034 & \\
\hline $\begin{array}{l}\text { o36 This organization is quite inward looking; it does not concern } \\
\text { itself with what is happening in the marketplace. }\end{array}$ & 2 & $1-2$ & .775 & .600 \\
\hline $\begin{array}{l}\text { o37 Ways of improving service to the customer are not given much } \\
\text { thought. }\end{array}$ & 2 & $1-3$ & .831 & .691 \\
\hline o38 Customer needs are not considered top priority here. & 2 & $1-2$ & .794 & .631 \\
\hline o39 This company is slow to respond to the needs of the customer. & 2 & $2-3$ & .824 & .679 \\
\hline $\begin{array}{l}\text { o40 This organization is continually looking for new opportunities in } \\
\text { the market place. }\end{array}$ & 3 & $2-3$ & .658 & .433 \\
\hline
\end{tabular}


TABLE 9. Median (Mdn) and Interquartile Range (IQR) of Items and Their Loadings and Communality in Principal Component Analysis One-Factor Solution $(n=176)$ of Participation

\begin{tabular}{lcccc}
\hline Participation & eigenvalue & & & 3.435 \\
& IQR & Factor & Communality \\
p41 Management involve people when decisions are made that & 3 & $2-3$ & .748 & .559 \\
$\quad$ affect them. & & & & .636 \\
p42 Changes are made without talking to the people involved them. & 2 & $2-3$ & .798 & .679 \\
p43 People do not have any say in decisions which affect their work. & 2 & $2-3$ & .824 & .718 \\
p44 People feel decisions are frequently made over their heads. & 3 & $2-3$ & .848 & .431 \\
p45 Information is widely shared. & 3 & $2-3$ & .657 & .411 \\
p46 There are often breakdowns in communication here. & 2 & $2-3$ & .641 & \\
\hline
\end{tabular}

TABLE 10. Median (Mdn) and Interquartile Range (IQR) of Items and Their Loadings and Communality in Principal Component Analysis One-Factor Solution $(n=176)$ of Performance Feedback

\begin{tabular}{lcrcr}
\hline Performance Feedback & Mdn & IQR & Factor & Communality \\
\hline $\begin{array}{l}\text { p47 People usually receive feedback on the quality of work they } \\
\text { have done. }\end{array}$ & 3 & $2-3$ & .732 & .535 \\
p48 People do not have any idea how well they are doing their job. & 2 & $2-3$ & .809 & .655 \\
p49 In general, it is hard for someone to measure the quality of their & 2 & $2-3$ & .775 & .600 \\
$\quad$ performance. & & & & \\
p50 People's performance is measured on a regular basis. & 3 & $2-3$ & .548 & .301 \\
p51 The way people do their jobs is rarely assessed. & 3 & $2-3$ & .637 & .406 \\
\hline
\end{tabular}

TABLE 11. Median (Mdn) and Interquartile Range (IQR) of Items and Their Loadings and Communality in Principal Component Analysis One-Factor Solution $(n=176)$ of Pressure to Produce

\begin{tabular}{lcccc}
\hline Pressure to Produce & Mdn & IQR & Factor & Communality \\
\hline & eigenvalue & & & 3.099 \\
p52 People are expected to do too much in a day. & 2 & $2-3$ & .814 & .663 \\
p53 In general, people's workloads are not particularly demanding. & 2 & $1-3$ & .767 & .589 \\
p54 Management require people to work extremely hard. & 3 & $2-3$ & .776 & .602 \\
p55 People here are under pressure to meet targets. & 3 & $2-3$ & .762 & .581 \\
p56 The pace of work here is quite relaxed. & 2 & $2-3$ & .815 & .664 \\
\hline
\end{tabular}

TABLE 12. Median (Mdn) and Interquartile Range (IQR) of Items and Their Loadings and Communality in Principal Component Analysis One-Factor Solution $(n=176)$ of Quality

\begin{tabular}{lcccc}
\hline Quality & Mdn & IQR & Factor & Communality \\
\hline q57 This company is always looking to achieve the highest & & & 2.365 \\
standards of quality. & 3 & $3-4$ & .872 & .760 \\
q58 Quality is taken very seriously. & 3 & $3-4$ & .895 & .801 \\
q59 People believe the company's success depends on high quality. & 3 & $3-4$ & .808 & .653 \\
$\begin{array}{l}\text { q60 This company does not have much of a reputation for top } \\
\text { quality products. }\end{array}$ & 2 & $1-2$ & .389 & .152 \\
\hline
\end{tabular}


TABLE 13. Median (Mdn) and Interquartile Range (IQR) of Items and Their Loadings and Communality in Principal Component Analysis One-Factor Solution $(n=176)$ for Reflexivity

\begin{tabular}{|c|c|c|c|c|}
\hline Reflexivity & Mdn & IQR & Factor & Communality \\
\hline eigenvalue & & & 2.811 & \\
\hline $\begin{array}{l}\text { r61 In this organization, the way people work together is readily } \\
\text { changed in order to improve performance. }\end{array}$ & 2 & $2-3$ & .779 & .607 \\
\hline $\begin{array}{l}\text { r62 The methods used by the organization to get the job done are } \\
\text { often discussed. }\end{array}$ & 2 & $2-3$ & .847 & .718 \\
\hline $\begin{array}{l}\text { r63 There are regular discussions as to whether people in the } \\
\text { organization are working effectively together. }\end{array}$ & 2 & $2-3$ & .761 & .579 \\
\hline $\begin{array}{l}\text { r64 In this organization, objectives are modified in light of changing } \\
\text { circumstances. }\end{array}$ & 3 & $2-3$ & .696 & .485 \\
\hline $\begin{array}{l}\text { r65 In this organization, time is taken to review organizational } \\
\text { objectives. }\end{array}$ & 3 & $2-3$ & .649 & .422 \\
\hline
\end{tabular}

TABLE 14. Median (Mdn) and Interquartile Range (IQR) of Items and Their Loadings and Communality in Principal Component Analysis One-Factor Solution $(n=176)$ for Supervisory Support

\begin{tabular}{|c|c|c|c|c|}
\hline Supervisory Support & Mdn & IQR & Factor & Communality \\
\hline eigenvalue & & & 3.210 & \\
\hline $\begin{array}{l}\text { s66 Supervisors here are really good at understanding people's } \\
\text { problems. }\end{array}$ & 3 & $2-3$ & .829 & .688 \\
\hline $\begin{array}{l}\text { s67 Supervisors show that they have confidence in those they } \\
\text { manage. }\end{array}$ & 3 & $3-3$ & .785 & .616 \\
\hline s68 Supervisors here are friendly and easy to approach. & 3 & $3-4$ & .800 & .640 \\
\hline $\begin{array}{l}\text { s69 Supervisors can be relied upon to give good guidance to } \\
\text { people. }\end{array}$ & 3 & $2-3$ & .722 & .521 \\
\hline $\begin{array}{l}\text { s70 Supervisors show an understanding of the people who work for } \\
\text { them. }\end{array}$ & 3 & $2-3$ & .863 & .745 \\
\hline
\end{tabular}

TABLE 15. Median (Mdn) and Interquartile Range (IQR) of Items and Their Loadings and Communality in Principal Component Analysis One-Factor Solution $(n=176)$ of Tradition

\begin{tabular}{lcccc}
\hline Tradition & Mdn & IQR & Factor & Communality \\
\hline $\begin{array}{l}\text { eigenvalue } \\
\text { t71 Senior management like to keep to established, traditional ways } \\
\text { of doing things. }\end{array}$ & 2 & $2-3$ & .822 & .676 \\
t72 $\begin{array}{l}\text { The way this organization does things has never changed very } \\
\text { much. }\end{array}$ & 2 & $2-3$ & .867 & .751 \\
t73 Management are not interested in trying out new ideas. & 2 & $2-2$ & .833 & .695 \\
t74 Changes in the way things are done here happen very slowly. & 3 & $2-3$ & .855 & .731 \\
\hline
\end{tabular}

TABLE 16. Median (Mdn) and Interquartile Range (IQR) of Items and Their Loadings and Communality in Principal Component Analysis One-Factor Solution $(n=176)$ of training

\begin{tabular}{|c|c|c|c|c|}
\hline Training & Mdn & IQR & Factor & Communality \\
\hline eigenvalue & & & 2.299 & \\
\hline $\begin{array}{l}\text { t75 People are not properly trained when there is a new machine or } \\
\text { piece of equipment. }\end{array}$ & 2 & $2-3$ & .812 & .659 \\
\hline $\begin{array}{l}\text { t76 People receive enough training when it comes to using new } \\
\text { equipment. }\end{array}$ & 3 & $2-3$ & .783 & .613 \\
\hline $\begin{array}{l}\text { t77 The company only gives people the minimum amount of } \\
\text { training they need to do their job. }\end{array}$ & 2 & $2-3$ & .831 & .690 \\
\hline t78 People are strongly encouraged to develop their skills. & 3 & $2-4$ & .581 & .337 \\
\hline
\end{tabular}


TABLE 17. Median (Mdn) and Interquartile Range (IQR) of Items and Their Loadings and Communality in Principal Component Analysis One-Factor Solution $(n=176)$ of Welfare

\begin{tabular}{lcccc}
\hline Welfare & Mdn & IQR & Factor & Communality \\
\hline & eigenvalue & & & 2.548 \\
w79 The company pays little attention to the interests of employees. & 2 & $2-3$ & .725 & .526 \\
w80 This company tries to look after its employees. & 3 & $2-3$ & .874 & .763 \\
w81 This company cares about its employees. & 3 & $2-3$ & .926 & .857 \\
w82 This company tries to be fair in its actions towards employees. & 3 & $3-3$ & .633 & .401 \\
\hline
\end{tabular}

TABLE 18. Median (Mdn) and Interquartile Range (IQR) of Items and Their Loadings and Communality in Principal Component Analysis One-Factor Solution $(n=176)$ of Health

\begin{tabular}{|c|c|c|c|c|c|}
\hline \multicolumn{2}{|l|}{ Health } & Mdn & & & \multirow[t]{2}{*}{ Communality } \\
\hline Health & \multicolumn{2}{|l|}{$\begin{array}{ll}\text { eigenvalue }\end{array}$} & & \\
\hline \multicolumn{2}{|r|}{$\begin{array}{l}\text { wa83 How do you evaluate your health compared to that of people } \\
\text { of the same age? }\end{array}$} & 8 & $\begin{array}{l}\text { IQR } \\
\text { 7-9 }\end{array}$ & $\begin{array}{c}\text { Factor } \\
2.002 \\
.885\end{array}$ & \\
\hline \multicolumn{2}{|r|}{$\begin{array}{l}\text { wa84 How do you evaluate your physical condition at the moment } \\
\text { compared with people of the same age? }\end{array}$} & 8 & \multirow{2}{*}{$\begin{array}{l}7-8 \\
7-9\end{array}$} & \multirow{2}{*}{$\begin{array}{l}.873 \\
.676\end{array}$} & \\
\hline \multicolumn{2}{|r|}{$\begin{array}{l}\text { wa85 At its best your work ability has been } 10 \text {. How do you evaluate } \\
\text { your work ability now? }\end{array}$} & 8 & & & \\
\hline
\end{tabular}

TABLE 19. Median (Mdn) and Interquartile Range (IQR) of Items and Their Loadings and Communality in Principal Component Analysis One-Factor Solution $(n=176)$ of Mental and Physical Work Ability

\begin{tabular}{lrrrr}
\hline Mental and Physical Work Ability & Mdn & IQR & Factor Communality \\
\hline & eigenvalue & & & 1.290 \\
wa86 How do you estimate your current work ability regarding the & 5 & $4-5$ & .803 & .645 \\
$\begin{array}{l}\text { physical demands of your work? } \\
\text { wa87 How do you estimate your current work ability regarding the }\end{array}$ & 4 & $4-4$ & .803 & .645 \\
\begin{tabular}{l} 
mental demands of your work? \\
\hline
\end{tabular}
\end{tabular}

TABLE 20. Median (Mdn) and Interquartile Range (IQR) of Items and Their Loadings and Communality in Principal Component Analysis One-Factor Solution $(n=176)$ of Mental Well-Being

\begin{tabular}{|c|c|c|c|c|c|c|c|}
\hline \multicolumn{2}{|c|}{ Mental Well-Being } & \multirow{2}{*}{ Mdn } & \multirow[t]{2}{*}{ IQR } & \multirow{2}{*}{$\frac{\text { Factor } 1}{2.901}$} & \multirow{2}{*}{$\begin{array}{c}\text { Factor } \mathbf{2} \\
2.823\end{array}$} & \multirow{2}{*}{$\begin{array}{c}\text { Factor } 3 \\
2.417\end{array}$} & \multirow[t]{2}{*}{ Communality } \\
\hline & eigenvalues & & & & & & \\
\hline smw89 & $\begin{array}{l}\text { Have you recently: been able to } \\
\text { concentrate on what you're doing? }\end{array}$ & 2 & $2-3$ & .522 & .036 & .624 & .664 \\
\hline smw90 & lost much sleep due to worry? & 2 & $1-3$ & .725 & .347 & .002 & .646 \\
\hline smw91 & $\begin{array}{l}\text { felt that you are playing a useful part in } \\
\text { things? }\end{array}$ & 2 & $2-2$ & .052 & .468 & .716 & .735 \\
\hline smw92 & $\begin{array}{l}\text { felt capable of making decisions about } \\
\text { things? }\end{array}$ & 2 & $2-2$ & .150 & .314 & .810 & .777 \\
\hline smw93 & felt constantly under strain? & 2 & $2-3$ & .776 & .285 & .207 & .726 \\
\hline smw94 & $\begin{array}{l}\text { felt you couldn't overcome your } \\
\text { difficulties? }\end{array}$ & 2 & $1-2$ & .436 & .639 & .195 & .637 \\
\hline smw95 & $\begin{array}{l}\text { been able to enjoy your normal day to day } \\
\text { activities? }\end{array}$ & 2 & $2-3$ & .734 & .183 & .384 & .719 \\
\hline smw96 & been able to face up to your problems? & 2 & $2-2$ & .465 & .160 & .618 & .624 \\
\hline smw97 & been feeling unhappy or depressed? & 2 & $1-2$ & .496 & .705 & .172 & .772 \\
\hline smw98 & been losing confidence in yourself? & 2 & $1-2$ & .239 & .783 & .351 & .794 \\
\hline smw99 & $\begin{array}{l}\text { been thinking of yourself as a worthless } \\
\text { person? }\end{array}$ & 1 & $1-2$ & .199 & .821 & .224 & .764 \\
\hline smw100 & $\begin{array}{l}\text { been feeling reasonably happy, all things } \\
\text { considered? }\end{array}$ & 2 & $2-2$ & .434 & .225 & .211 & .284 \\
\hline
\end{tabular}


TABLE 21. Median (Mdn) and Interquartile Range (IQR) of Items and Their Loadings and Communality in Principal Component Analysis One-Factor Solution $(n=176)$ of Job Satisfaction

\begin{tabular}{lrrrr}
\hline Job Satisfaction & Mdn & IQR & Factor & Communality \\
\hline & eigenvalue & & 1.687 & \\
js101 Generally speaking, I am very satisfied with this job. & 8 & $7-9$ & .918 & .844 \\
js102 I am generally satisfied with the kind of work I do in this job. & 8 & $7-9$ & .918 & .844 \\
\hline
\end{tabular}

TABLE 22. Median (Mdn) and Interquartile Range (IQR) of Items and Their Loadings and Communality in Principal Component Analysis One-Factor Solution $(n=176)$ of Work Absorption

\begin{tabular}{lcccc}
\hline Work Absorption & & Mdn & IQR & Factor Communality \\
\hline & eigenvalue & & \multicolumn{2}{c}{2.905} \\
wf103 When I am working, I think about nothing else. & 5 & $4-6$ & .713 & .509 \\
wf104 I get carried away by my work. & 5 & $4-6$ & .895 & .800 \\
wf105 When I am working, I forget everything else around me. & 5 & $3-5$ & .902 & .814 \\
wf106 I am totally immersed in my work. & 5 & $4-6$ & .884 & .782 \\
\hline
\end{tabular}

TABLE 23. Median (Mdn) and Interquartile Range (IQR) of Items and Their Loadings and Communality in Principal Component Analysis One-Factor Solution $(n=176)$ of Work Enjoyment

\begin{tabular}{lcccc}
\hline Work Enjoyment & Mdn & IQR & Factor Communality \\
\hline & eigenvalue & & \multicolumn{2}{c}{3.419} \\
we107 When I am working very intensely, I feel happy. & 5 & $4-6$ & .894 & .799 \\
we108 I do my work with a lot of enjoyment. & 5 & $4-5.5$ & .947 & .897 \\
we109 I feel happy during my work. & 5 & $4-6$ & .921 & .849 \\
we110 I feel cheerful when I am working. & 5 & $4-6$ & .935 & .874 \\
\hline
\end{tabular}

TABLE 24. Median (Mdn) and Interquartile Range (IQR) of Items and Their Loadings and Communality in Principal Component Analysis One-Factor Solution $(n=176)$ of Intrinsic Work Motivation

\begin{tabular}{lcccc}
\hline Intrinsic Work Motivation & Mdn & IQR & Factor & Communality \\
\hline & eigenvalue & & & 3.423 \\
iwm111 I do my work simply for the pleasure that it brings me. & 3.5 & $2-5$ & .840 & .705 \\
iwm112 I find that I also want to work in my free time. & 3 & $2-5$ & .647 & .418 \\
iwm113 I work because I enjoy. & 4 & $3-5$ & .819 & .670 \\
iwm114 When I am working on something, I am do it for myself. & 4 & $2-5$ & .693 & .480 \\
iwm115 I would still do this work, even if I received less pay. & 3 & $1-5$ & .736 & .541 \\
iwm116 I get my motivation from the work itself, and not from the & 4 & $3-5$ & .780 & .609 \\
$\quad$ rewards it brings. & & & & \\
\hline
\end{tabular}

TABLE 25. Median (Mdn) and Interquartile Range (IQR) of Items and Their Loadings and Communality in Principal Component Analysis One-Factor Solution $(n=176)$ of Personality

\begin{tabular}{|c|c|c|c|c|c|c|c|}
\hline \multirow{2}{*}{\multicolumn{2}{|c|}{ Personality }} & \multicolumn{6}{|c|}{ Loadings of Rotated Factors } \\
\hline & & \multirow[t]{2}{*}{ Mdn } & \multirow[t]{2}{*}{ IQR } & \multirow{2}{*}{$\begin{array}{c}\text { Factor } 1 \\
2.751\end{array}$} & \multirow{2}{*}{$\frac{\text { Factor } 2}{1.593}$} & \multirow{2}{*}{$\frac{\text { Factor } 3}{1.136}$} & \multirow[t]{2}{*}{ Communality } \\
\hline & eigenvalue & & & & & & \\
\hline p117 & $\begin{array}{l}\text { Self-confidence describes a belief in one's } \\
\text { own prospects and confidence about } \\
\text { managing demanding tasks. }\end{array}$ & 8 & $7-9$ & .696 & .330 & .092 & .601 \\
\hline p118 & $\begin{array}{l}\text { Social courage describes daring and will to } \\
\text { air one's opinion in company and speak out. }\end{array}$ & 8 & $6-9$ & .840 & .138 & -.020 & .725 \\
\hline p119 & $\begin{array}{l}\text { Dominance describes how to take the } \\
\text { initiative, wade into things or manage. }\end{array}$ & 7 & $6-8$ & .864 & .080 & -.155 & .776 \\
\hline p120 & $\begin{array}{l}\text { Are you a person, who thinks of anyone but } \\
\text { yourself. }\end{array}$ & 4 & $3-6$ & .249 & .437 & -.598 & .611 \\
\hline
\end{tabular}


TABLE 25. (continued)

\begin{tabular}{|c|c|c|c|c|c|c|c|}
\hline \multirow{2}{*}{\multicolumn{2}{|c|}{ Personality }} & \multicolumn{6}{|c|}{ Loadings of Rotated Factors } \\
\hline & & \multirow{2}{*}{$\frac{M d n}{8}$} & \multirow{2}{*}{$\frac{\text { IQR }}{7-9}$} & \multirow{2}{*}{$\begin{array}{c}\text { Factor } 1 \\
.614\end{array}$} & \multirow{2}{*}{$\begin{array}{l}\text { Factor } 2 \\
-.101\end{array}$} & \multirow{2}{*}{$\frac{\text { Factor } 3}{.380}$} & \multirow{2}{*}{ Communality } \\
\hline p121 & How hardheaded and strong are you? & & & & & & \\
\hline p122 & Do you feel easy and relaxed about things? & 5.5 & $4-7$ & .043 & .815 & -.028 & .667 \\
\hline p123 & $\begin{array}{l}\text { How much do you want to get through new } \\
\text { and different things? How much changes do } \\
\text { you want? }\end{array}$ & 7 & $6-8$ & .171 & .671 & .126 & .495 \\
\hline p124 & How effective and energetic you are? & 8 & $7-9$ & .556 & .239 & .360 & .496 \\
\hline p125 & $\begin{array}{l}\text { How do you feel that you can affect in your } \\
\text { life while you are not depended of the fate? }\end{array}$ & 8 & $6-9$ & .190 & .294 & .675 & .578 \\
\hline
\end{tabular}

TABLE 26. Median (Mdn) and Interquartile Range (IQR) of Items and Their Loadings and Communality in Principal Component Analysis One-Factor Solution $(n=176)$ of Self-Esteem

\begin{tabular}{|c|c|c|c|c|c|}
\hline \multirow[b]{2}{*}{ Self-Esteem } & \multirow[b]{2}{*}{ Mdn } & \multirow[b]{2}{*}{ IQR } & \multicolumn{2}{|c|}{$\begin{array}{c}\text { Loadings of Rotated } \\
\text { Factors }\end{array}$} & \multirow[b]{2}{*}{ Communality } \\
\hline & & & Factor 1 & Factor 2 & \\
\hline eigenvalue & & & 2.818 & 2.680 & \\
\hline s126 On the whole, I am satisfied with myself. & 4 & $4-4.75$ & .666 & .376 & .584 \\
\hline s127 At times I think I am no good at all. & 2 & $2-3$ & .177 & .750 & .593 \\
\hline s128 I feel that I have a number of good qualities. & 4 & $4-5$ & .661 & .072 & .442 \\
\hline $\begin{array}{l}\text { s129 I am able to do things as well as most other } \\
\text { people. }\end{array}$ & 4 & $4-5$ & .832 & .195 & .731 \\
\hline s130 I feel I do not have much to be proud of. & 1 & $1-2$ & .332 & .420 & .286 \\
\hline s131 I certainly feel useless at times. & 2 & $1-3$ & .134 & .761 & .596 \\
\hline $\begin{array}{l}\text { s132 I feel that I am a person of worth, at least on an } \\
\text { equal plane with others. }\end{array}$ & 5 & $4-5$ & .734 & .105 & .550 \\
\hline s133 I wish I could have more respect for myself. & 3 & $2-4$ & .041 & .703 & .495 \\
\hline s134 All in all, I am inclined to feel that I am a failure. & 1 & $1-2$ & .482 & .596 & .587 \\
\hline s135 I take a positive attitude toward myself. & 4 & $3-5$ & .559 & .565 & .632 \\
\hline
\end{tabular}

TABLE 27. Median (Mdn) and Interquartile Range (IQR) of Items and Their Loadings and Communality in Principal Component Analysis One-Factor Solution $(n=176)$ of Optimism

\begin{tabular}{|c|c|c|c|c|c|c|}
\hline \multirow[b]{2}{*}{ Optimism } & \multirow[b]{2}{*}{ Mdn } & \multirow[b]{2}{*}{ IQR } & \multicolumn{3}{|c|}{ Loadings of Rotated Factors } & \multirow[b]{2}{*}{ Communality } \\
\hline & & & Factor 1 & Factor 2 & Factor 3 & \\
\hline eigenvalue & & & 2.852 & 2.348 & 1.219 & \\
\hline $\begin{array}{l}\text { O136 In uncertain times, I usually expect the } \\
\text { best. }\end{array}$ & 3 & $2-3$ & 680 & -.268 & -.062 & .538 \\
\hline O137 It's easy for me to relax. & 3 & $2-3$ & .537 & -.395 & -.385 & .593 \\
\hline O138 If something can go wrong for me, it will. & 1 & $1-2$ & .421 & .541 & -.302 & .561 \\
\hline $\begin{array}{l}\text { O139 I always look on the bright side of } \\
\text { things. }\end{array}$ & 2 & $2-3$ & .764 & -.263 & -.046 & .656 \\
\hline O140 I'm always optimistic about my future. & 3 & $2-4$ & .685 & -.018 & -.107 & .480 \\
\hline O141 I enjoy my friends a lot. & 3 & $3-4$ & .460 & -.422 & -.052 & .393 \\
\hline O142 It's important for me to keep busy. & 3 & $2-3.25$ & .148 & -.374 & .773 & .760 \\
\hline O143 I hardly ever expect things to go my way. & 1 & $1-1$ & .503 & .554 & .250 & .622 \\
\hline $\begin{array}{l}\text { O144 Things never work out the way I want } \\
\text { them to. }\end{array}$ & 1 & $0-1$ & .465 & .580 & .010 & .553 \\
\hline O145 I don't get upset too easily. & 2 & $1-3$ & .509 & -.207 & -.101 & .313 \\
\hline $\begin{array}{l}\text { O146 I'm a believer in the idea that "every } \\
\text { cloud has a silver lining." }\end{array}$ & 3 & $2-3$ & .507 & -.113 & .313 & .368 \\
\hline $\begin{array}{l}\text { O147 I rarely count on good things happening } \\
\text { to me. }\end{array}$ & 1 & $1-2$ & .567 & .431 & .275 & .583 \\
\hline
\end{tabular}




\section{RESULTS}

Tables 1-28 show the results of the principal component analyses concerning the 147 items. Items a1-a5 elicited autonomy $(\alpha=.794)$, in which the Kaiser-Meyer-Olkin (KMO) measure was .776 and Bartlett's test of sphericity 294 $(d f=10, p<.001)$ indicated that the samples met the criteria for factor analysis. The one-factor solution explained $56 \%$ of the total variance (Table 1). Items a1 and a4 had the highest loadings on this factor (factor loadings .828 and .845). Inter-item correlations varied from .20 to .64; they were lowest between questions a 3 and a5 and highest between questions a3 and a4. The lowest correlations $(<.4)$ were associated with question a5. This one-factor solution created item 1 "Management trusts on people and lets them make their own decisions".

Items c6-c10 elicited clarity of organizational goals $(\alpha=.815)$, in which the KMO measure was .830 and Bartlett's test of sphericity 264 $(d f=10, p<.001)$. Table 2 shows the results of the one-factor solution, which explained $58 \%$ of the total variance. All inter-item correlations between questions c6-c10 were over .40; they were highest $(r=.55)$ between questions $\mathrm{c} 9$ and c10. This one-factor solution created item 2 "People have a good understanding of what the organization is doing".

Table 3 shows one-factor solution of items e11-e14, on efficiency, explaining $68 \%$ of the total variance. Cronbach's $\alpha$ was .839 , the KMO measure was .780 and Bartlett's test of sphericity value $282(d f=6, p<.001)$. Inter-item correlations between questions e11-e14 varied from .49 (between questions e12 and e13) to .71 (between questions e11 and e14). This onefactor solution created item 3 "Time and money could be saved if work were better planned and organised".

Items e15-e19 elicited effort $(\alpha=.775)$, in which the KMO measure was .747 and Bartlett's test of sphericity $253(d f=10, p<.001)$. Table 4 shows the results of the one-factor solution. Interitem correlations were lowest $(r=.21)$ between questions e15 and e19 and highest $(r=.56)$ between questions e16 and e18. The first factor explained 54\% of the total variance. Question e18 had the highest loading on this factor (communality .709). This one-factor solution created item 4 "People are prepared to make their best to do a good job".

Items f20-f24 elicited a formalization $(\alpha=.807)$, in which the KMO measure was .827 and Bartlett's test of sphericity $252(d f=10$, $p<.001)$. Table 5 shows the results of the onefactor solution, which explain $57 \%$ of the total variance. Inter-item correlations varied from .35 between questions f20 and f24 to .58 between questions $\mathrm{f} 22$ and $\mathrm{f} 24$. This one-factor solution created item 5 "It is necessary to follow rules to get the work done".

Items i25-i30 elicited innovation and flexibility $(\alpha=.871)$. The KMO measure of the onefactor solution, which explained $61 \%$ of the total variance, was .879 and Bartlett's test of sphericity $452(d f=15, p<.001)$ (Table 6). Question i26 had highest loading on this factor (communality .682). The lowest interitem correlation $(r=.41)$ was found between questions i25 and i27. Most correlation coefficients varied between .53 and .57. This onefactor solution created item 6 "The organization is quick to respond when changes need to be made".

Items i31-i35 elicited integration $(\alpha=.805)$, in which the KMO measure was .737 and Bartlett's test of sphericity $296(d f=10, p<.001)$. Interitem correlations varied from .27 (questions i31 and i34) to .66 (questions i31 and i35). The results of the one-factor solution explained $56 \%$ of the total variance (Table 7). Question i33 had highest loading on this factor (communality .609). This one-factor solution created item 7 "People are prepared to share information with each other".

The KMO measure was .822 and Bartlett's test of sphericity $323(d f=10, p<.001)$ of items $036-040$, which elicited outward focus $(\alpha=.837)$. The results of the one-factor solution explained $61 \%$ of the total variance (Table 8 ). Inter-item correlations between questions varied from .38 to .68 . This one-factor solution created item 8 "The customer service is being continuously improved". 
Items $\mathrm{p} 41-46$ elicited participation $(\alpha=.850)$, in which the KMO measure was .838 and Bartlett's test of sphericity $424(d f=15$, $p<.001)$. The lowest inter-item correlation $(r=.33)$ was found between questions $\mathrm{p} 42$ and p43 and the highest $(r=.70)$ between questions $\mathrm{p} 43$ and $\mathrm{p} 44$. The one-factor solution explained $57 \%$ of the total variance (Table 9). This onefactor solution created item 9 "People feel decisions are frequently made without talking to the people involved".

Items p47-p51 elicited performance feedback $(\alpha=.735)$, in which the KMO measure was .775 and Bartlett's test of sphericity 196 $(d f=10, p<.001)$. Questions p50 and p51 did not correlate well between other questions; correlation coefficients varied from .24 to .39 . Other correlations varied from .45 to .58 . The results of the one-factor solution explained $50 \%$ of the total variance (Table 10). This onefactor solution created item 10 "People receive feedback on the quality of their work".

Items p52-p56 elicited pressure to produce with $\alpha=.845$, the KMO measure .859 and Bartlett's test of sphericity $323(d f=10$, $p<.001)$. All inter-item correlations were between .47 and .57 . The one-factor solution explained $62 \%$ of the total variance (Table 11). This one-factor solution created item 11 "The pace of work here is quite relaxed".

Items q57-q60 elicited quality $(\alpha=.732)$, in which the KMO measure was .700 and Bartlett's test of sphericity 237 ( $d f=6, p<.001)$. Low inter-item correlations were found between questions q57 and q60, between q58 and q60, and between $\mathrm{q} 59$ and $\mathrm{q} 60(.15, .24$ and .23 , respectively). Other correlations were quite high, from .56 to .76 between questions q57 and q58. Question q58 had the highest loading on this factor (communality .801), but question q60 loaded quite poorly (.389) to factor with communality (.152). The one-factor solution explained 59\% of the total variance (Table 12). This one-factor solution created item 12 "Quality is taken very seriously".

The one-factor solution of items r61-r65 elicited reflexivity. Cronbach's a was .802 , the KMO measure .772 and Bartlett's test of sphericity $277(d f=10, p<.001)$. Inter-item correlations varied from .33 to .64 between questions r61-r65. The factor explained $56 \%$ of the total variance (Table 13). Question r62 had the highest loading on this factor (communality .847). This one-factor solution created item 13 "The methods used by the organization to get the job done are often discussed".

Items s66-s70 elicited supervisory support $(\alpha=.858)$, in which the KMO measure was .859 and Bartlett's test of sphericity $371(d f=10$, $p<.001)$. Inter-item correlations were moderate, between .41 and .66 . The results of the one-factor solution explained $64 \%$ of the total variance (Table 14). Question s70 had the highest loading on this factor (communality .745). This onefactor solution created item 14 "Supervisors show good understanding and guidance to the people who work for them".

Items $\mathrm{t} 71-\mathrm{t} 74$ elicited tradition $(\alpha=.865)$, in which the KMO measure was .807 and Bartlett's test of sphericity 323 ( $d f=6, p<.001$ ). Interitem correlations were homogenous between .57 and .66. This one-factor solution explained $71 \%$ of the total variance (Table 15). This onefactor solution created item 15 "The way this organization does things changes slowly".

Items t75-t78 elicited training ( $\alpha=.747$ ), in which the KMO measure was .738 and Bartlett's test of sphericity $168(d f=6, p<.001)$ Inter-item correlations of question t78 were low (under .39) between other questions. Other correlations were between .50 and .57 . This one-factor explained $58 \%$ of the total variance (Table 16). This onefactor solution created one-factor item 16 "The company gives people training they need to do their job".

Items w79-w82 elicited welfare $(\alpha=.780)$, in which the KMO measure was .697 and Bartlett's test of sphericity 293 ( $d f=6, p<.001$ ). Interitem correlation between questions w79 and w82 was low $(r=.18)$. Other correlation coefficients varied from .40 to .56 . The results of the onefactor solution explained $64 \%$ of the total variance. Question w81 had the highest loading on this factor (communality .857) (Table 17). This one-factor solution created item 17 "Our company cares about its employees". 
Items wa83-wa85 elicited health $(\alpha=.749)$, in which the KMO measure was .618 and Bartlett's test of sphericity 149 ( $d f=3, p<.001)$. Interitem correlation was quite low between questions wa83 and wa85 $(r=.40)$ and between questions wa84 and wa85 $(r=.37)$, but quite high between questions wa83 and wa84 $(r=.71)$. This factor explained $67 \%$ of the total variance (Table 18 ). This one-factor solution created item 18 "How do you evaluate your health compared to that of people of the same age?".

Items wa86-wa87 elicited mental and physical work ability $(\alpha=.449)$, in which the KMO measure was .500 and Bartlett's test of sphericity $15(d f=1, p<.001)$. The inter-item correlation between questions was low $(r=.29)$. The factor explained $65 \%$ of the total variance. This onefactor solution shown in Table 19 created item 19 "How do you estimate your current work ability?"

Question wa88 (Mdn 6; interquartile range from 3 to 7) alone constructed item 20 "Do you nowadays feel stress like a person who feels strain, nervousness, distress or loses much sleep due to worry?"

Items smw89-smw100 elicited mental wellbeing $(\alpha=.901)$, in which the KMO measure was .910 and Bartlett's test of sphericity 1084 $(d f=66, p<.001)$. Inter-item correlations between questions varied from .24 (questions smw91 and smw100) to .71 (questions smw98 and smw99). Table 20 shows the results of the varimax rotation of the three-factor solution. The first rotated factor explained $24 \%$, the second factor $24 \%$ and the third factor explained $20 \%$ of the total variance. Question smw100 had only a weak association with the first factor. This threefactor solution created items 21-23: factor 1 "Have you been able to enjoy your normal day to day activities without strain?" as item 21, factor 2 "Have you been thinking of yourself as a worthless person?" as item 23 and factor 3 "Have you recently felt capable of making decisions about things?" as item 22.

Items js101-js102 elicited work satisfaction ( $\alpha=.812$, inter-item correlation .69), in which the KMO measure was .500 and Bartlett's test of sphericity $110(d f=1, p<.001)$. The factor explained $84 \%$ of the total variance (Table 21 ).
This one-factor solution created item 24 "Generally I am very satisfied with my job".

Items wf103-wf106 elicited work absorption $(\alpha=.869)$, in which the KMO measure was .813 and Bartlett's test of sphericity $377(d f=6$, $p<.001)$. Inter-item correlations between questions varied from .48 to .77 . The results of the one-factor solution explained $73 \%$ of the total variance (Table 22). This solution created item 25 "When I am working, I forget everything else around me".

Items we107-we110 elicited work enjoyment in work $(\alpha=.943)$, in which the KMO measure was .864 and Bartlett's test of sphericity 645 $(d f=6, p<.001)$. Inter-item correlations between questions were quite high, from .74 to .86 . The results of the one-factor solution explained $86 \%$ of the total variance (Table 23). It created item 26 "I do my work with a lot of enjoyment".

Items iwm111-iwm116 elicited intrinsic work motivation $(\alpha=.841)$, in which the KMO measure was .832 and Bartlett's test of sphericity $421(d f=15, p<.001)$. Inter-item correlations between questions were moderate, from .33 to .69. The results of the one-factor solution explained $57 \%$ of the total variance (Table 24). This factor solution created item 27 "I do my work for the pleasure that it brings me".

Items p117-p125 elicited personality $(\alpha=.735)$, in which the KMO measure was .773 and Bartlett's test of sphericity $370(d f=36$, $p<.001$ ). Inter-item correlations varied from .02 to .42 between questions p120 and p125. Correlations between questions p117, p118 and p119 were between .53 and .70 . Table 25 show the results of varimax rotation of the three-factor solution. The first rotated factor explained $31 \%$ of the total variance, the second factor $18 \%$ and the third factor $13 \%$ of the total variance. This three-factor solution created item 28 "I am confident that I can manage even demanding tasks" as factor 1, item 30 "I feel easy and relaxed about things" as factor 2 and item 29 "I control my own life and I am not driven by random chance" as factor 3 .

Items s126-s135 elicited self-confidence ( $\alpha=.837)$, in which the KMO measure was .866 and Bartlett's test of sphericity $559(d f=45$, 
$p<.001)$. Inter-item correlations varied from .15 (between s128 and s133) to .63 (between questions s126 and s135). Table 26 shows the results of the varimax rotation of the two-factor solution. The first factor explained $28 \%$ and the second factor $27 \%$ of the total variance. Question s130 had only weak loading on both two factors. The first factor created item 31 "I feel positive about myself" and second factor created item 32 "Every now and then I feel useless".

Items o136-o147 elicited optimism $(\alpha=.761)$, in which the KMO measure was .786 and Bartlett's test of sphericity $468(d f=66$, $p<.001$ ) Table 27 shows the results of varimax rotation of the three-factor solution. The first factor explained $24 \%$, the second factor $20 \%$ and the third factor explained $10 \%$ of the total variance. This three-factor solution created item 33 "I always look on the bright side of things". The questions' inter-item correlations were loaded to the first factor. These factors varied between .29 and .55 . Results of factors 2 and 3 were not included in the shorter questionnaire, because factor 2 was opposite to factor 1 and the results of factor 3 were not important for good work-related well-being.

On the basis of the 147-item questionnaire, a 33-item questionnaire was developed with principal component analysis (Table 28). The repeatability of the shorter questionnaire was good and most $\kappa$ values were $.50-.94(n=19$, $p<.001, \alpha=.91)$.

\section{TABLE 28. 33-Item Questionnaire}

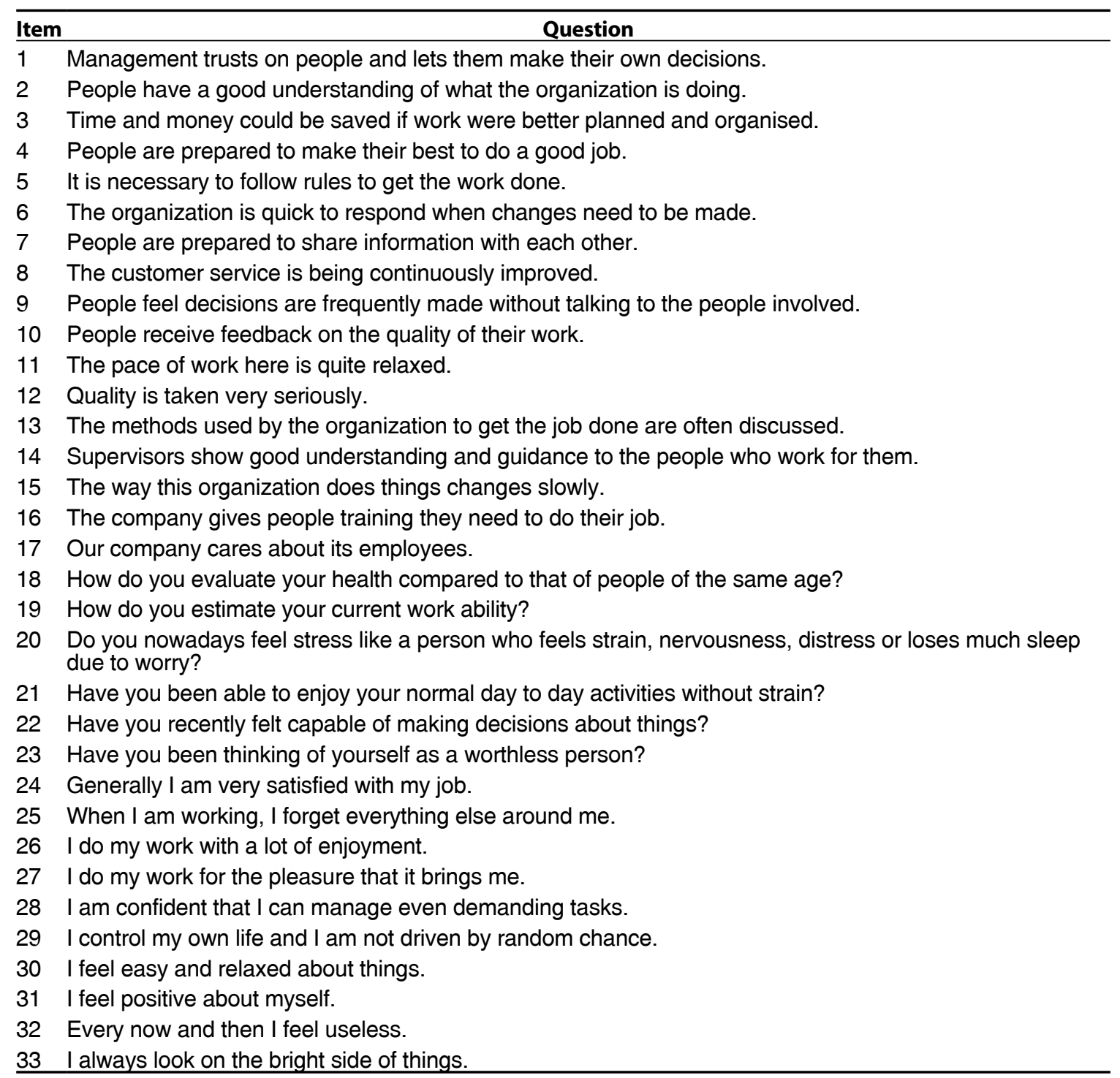




\section{DISCUSSION}

A short and reliable work-related well-being questionnaire was the main result of the study. The shorter version was developed for the mobile and Internet questionnaires. From the extensive questionnaire the shorter questionnaire with 33 items was developed by principal component analysis. In the current study, the phenomenon of work-related well-being was investigated among volunteers in a heterogeneous study population representing different occupations. The questionnaire is suitable for the Internet and mobile questionnaire applications.

There are some limitations to the present study. One central part of work-related wellbeing, namely the work environment, was not researched. Because of the extensive questionnaire in this study we focused only on organizational and intrinsic factors. Due to the small sample size occupations could not be classified. The generalizability of this study may be limited to some extent by the nature of the size of the sample. In addition, most participants were women.

Despite some limitations, there are significant strengths in this study. We developed a compact instrument that would be sufficient for measuring work-related well-being. Peto, Jenkinson, Fitzpatrick, et al. reported a closely related study but the main difference is that they generated questionnaire items from interviews [48]. On the other hand, Hayes, Perander, Smecko, et al. developed a 50-item instrument for assessing work safety based on a literature review as in this study [49]. The long questionnaire makes it possible to identify work-related wellbeing concerning intrinsic and organizational factors. The data for this study were gathered in combination with multiple variables to quantify work-related well-being. The original items were based on reported questionnaires. The items described organizational and intrinsic factors of work-related well-being.

In addition, further studies should also include promotion of work-related well-being [50] and items on the work environment. The latter should cover occupational climate [51, 52], indoor climate [53, 54], working conditions and work postures [55].

It is obvious that employees do not want to answer long questionnaires. Therefore, a shorter questionnaire may increase the response rate and the results may represent the target population better. It is also easier to research work-related well-being at workplaces and inform organizations and employees about the levels of work-related well-being using more competent questionnaires. In addition, short well-being questionnaires enable administering questionnaires via mobile phones and the Internet. A short well-being questionnaire also enables measuring longitudinal well-being [56].

In conclusion, from our results we were able to determine that the shorter, 33-item version of the original 147-item questionnaire well estimates the perspectives on work-related well-being. The applications of our results, like mobile work-related well-being questionnaires, may encourage organizations to evaluate workrelated well-being at workplaces. In addition, items should be researched in a larger population. Measuring changes over time, e.g., with weekly mobile questionnaires, may be more helpful in identifying the complex phenomenon of workrelated well-being.

\section{REFERENCES}

1. Mayo E. The Human problems of an industrial civilization. New York, NY, USA: Macmillan; 1933.

2. Warr P. Well-being and the workplace. In: Kahneman D, Diener E, Schwarz N, editors. Well-being: the foundations of hedonistic psychology. New York, NY, USA: Russell Sage Foundation; 1999. p. 397-412.

3. Campbell JD, Chew B, Scratchley IS. Cognitive and emotional reactions to daily events: the effects of self-esteem and selfcomplexity. J Pers. 1991;55:473-505.

4. Warr P. The measurement of well-being and other aspects of mental health. J Occup Psychol. 1990;63:193-210.

5. Utriainen K. Appreciative reciprocity as the core of well-being at work of ageing 
nurses. Acta Univ Oul D 1014. Oulu, Finland: Oulu University Press; 2009. In Finnish, with an abstract in English. Retrieved August 30, 2011, from: http:// herkules.oulu.fi/isbn9789514291128/ isbn9789514291128.pdf

6. Xanthopoulou D, Bakker AB, Demerouti E, Schaufeli WB. Work engagement and financial returns: a diary study on the role of job and personal resources. J Occup Organ Psychol. 2009;82:183-200.

7. Grant AM, Christianson MK, Price RH. Happiness, health, or relationships? Managerial practices and employee well-being tradeoffs. Academy of Management Perspectives. 2007;21:51-63.

8. Loretto W, Popham F, Platt S, Pavis S, Hardy G, Macleod L, et al. Assessing psychological well-being: a holistic investigation of NHS employees. Int Rev Psychiatry. 2005;17 (5):329-36.

9. Feldt T, Kinnunen U, Mauno S. A mediational model of sense of coherence in the work context: a one-year follow-up study. J Organ Behav. 2000;21(4):461-76.

10. Xanthopoulou D, Bakker AB, Demerouti E, Schaufeli W.B. 2009. Reciprocal relationships between job resources, personal resources and work engagement. J Vocat Behav. 2009;74:235-44.

11. Savinainen $M$, Nygård $C-H$, Jääskeläinen M, Orsila R, Puurtinen H-G. Feasibility of new technology in assessing work and leisure-time load-a pilot study. In: Saarela KL, Nygård CH, Lusa S, editors. Promotion of Well-Being in Modern Society. Proceedings of the 38th Annual Congress of the Nordic Ergonomics Society (NES). Tampere, Finland: NES; 2006. p. 57-9.

12. Bakker AB, Demerouti E. The job demands resources model: state of the art. $\mathbf{J}$ Manag Psychol. 2007;22:309-28 (DOI:10 $.1108 / 02683940710733115$ )

13. Schaufeli W, Salanova M. Work engagement. An emerging psychological concept and its implications for organizations. In: Gilliland SW, Steiner DD, Skarlicki DP, editors. Managing social and ethical issues in organizations. Greenwich, CT, USA: Information Age; 2007. p. 135-177.

14. Patterson $M$, West $M$, Shackleton $V$, Lawthom R, Maitlis S, Robinson D, et al. 2004. Development \& validation of an organisational climate measure. Birmingham, UK: Aston University; 2004.

15. Patterson M, Warr P, West M. Organisational climate and company productivity: the role of employee affect and employee level. J Occup Organ Psychology. 2004;77: 193-216.

16. Ilmarinen J. Towards a longer worklife! Ageing and the quality of worklife in the European Union. Helsinki, Finland: Finnish Institute of Occupational Health, Ministry of Social Affairs and Health; 2006.

17. Heponiemi $T$, Kouvonen $A$, Vänskä $J$, Halila H, Sinervo T, Kivimäki $M$, et al. Health, psychosocial factors and retirement intentions among Finnish physicians. Occup Med (Chic Ill). 2008;58(6):406-12.

18. Tuomi K, Eskelinen L, Toikkanen J, Järvinen E, Ilmarinen J, Klockars M. Work load and individual factors affecting work ability among aging municipal employees. Scand J Work Environ Health. 1991; 17(suppl 1),128-34.

19. Elo A-L, Hinkkanen S. 1992. Occupational stress questionnaire: user's instructions. Helsinki, Finland: Finnish Institute of Occupational Health; 1992.

20. Goldberg D. The detection of psychiatric illness by questionnaire: a technique for the identification and assessment of nonpsychotic psychiatric illness. London, UK: Oxford University Press; 1992.

21. Hackman JR. Work redesign. Reading, MA, USA: Addison Wesley; 1980.

22. Bakker AB. Development and validation of the work-related flow inventory (WOLF) Utrecht, The Netherlands: Utrecht University, Department of Social and Organisational Psychology, and Research Institute Psychology and Health; 2006.

23. Ojanen M. Graafiset analogia-asteikot elämänlaadun ja hyvinvoinnin mittauksessa [Graphical analogy scales measuring life quality and well-being]. In: Talo S, editor. Toimintakyky-viitekehyksestä arviointiin ja mittaamiseen [Capacity from the framework to evaluation and measuring]. Turku, Finlad: KELA (n Sosiaali- ja terveysturvankatsauksia); 2001. p. 207-25. 
24. Rosenberg M. Society and the adolescent self-image. Princeton, NJ, USA: Princeton University Press; 1965.

25. Scheier MF, Carver CS. Optimism, coping, and health: assessment and implications of generalized outcome expectancies. Health Psychol. 1985;4:219-47.

26. Bakker AB, Schaufeli WB. Positive organizational behavior: Engaged employees in flourishing organizations. J Organ Behav. 2008;29:147-54.

27. Van de Kerckhove J. Towards a new philosophy in the prevention strategy on health and safety at work: pro-activity and well-being. European Journal of Social Quality. 2006;6(2):53-79.

28. Kinnunen U, Mauno S, Feldt T. Työ leipälajina-työhyvinvoinnin psykologiset perusteet [Work-psychological foundations of work-related well-being]. Jyväskylä, Finland: PS-kustannus; 2005.

29. Maslach C, Schaufeli WB, Leiter MP. Job burnout. Annu Rev Psychol. 2001;52: 397-422.

30. Schaufeli WB, Salanova M, GonzálezRomá V, Bakker AB. The measurement of engagement and burnout: a two sample confirmatory factor analytic approach. J Happiness Stud. 2002;3:71-92. Retrieved August 30, 2011, from: http:// www.springerlink.com/content/hc82g16 ytw7fj728/fulltext.pdf

31. Demerouti E, Bakker AB, Janssen PPM, Schaufeli W. Burnout and engagement at work as a function of demands and control. Scand J Work Environ Health. 2001;27:279-86.

32. Demerouti E, Bakker AB, Nachreiner F, Schaufeli W. The job demands-resources model of burnout. J Appl Psychol. 20011;86:499-512 (DOI:10.1037/0021-901 0.86.3.499).

33. Manka M-L. Topteam: towards a productive, learning and positive work community and personal well-being; an action research of a transformation process in a food production plant-by a quantum leap and a cock's step [academic dissertation]. Acta Universitatis Tamperensis 668. Tampere, Finland: University of Tampere; 1999.
34. Argyle M. The social psychology of work. London, UK: Penguin Books; 1989.

35. Scheier MF, Carver CS. Optimism, coping, and health: assessment and implications of generalized outcome expectancies. Health Psychol. 1985;4:219-47.

36. Nelson D, Cooper CL. 2005. Guest editorial: stress and health: a positive direction. Stress Health. 2005;21:73-5 (DOI:10.1002/smi.1053).

37. Nelson DL, Simmons BL. Eustress: an elusive construct, an engaging pursuit. In: Perrewe PL, Ganster DC, editors. Emotional and physiological processes and positive intervention strategies. Amsterdam, The Netherlands: Elsevier; 2004. p. 265-322.

38. Utriainen K. Substantiivinen teoria ikääntyvien sairaanhoitajien hyvinvoinnista [Substantive theory of well-being of ageing nurses] [licenciate work]. Oulu, Finland: University of Oulu; 2006.

39. Mäkikangas A, Kinnunen U. Psychosocial work stressors and well-being: self-esteem and optimism as moderators in a one-year longitudinal sample. Pers Individ Dif. 2003;35:537-57.

40. Arnetz BB. Subjective indicators as a gauge for improving organisational wellbeing. An attempt to apply the cognitive activation theory to organisations. Psychoneuroendocrinology. 2005;30:1022-6.

41. Schaufeli WB, Bakker AB, Van Rhenen W. 2009. How changes in job demands and resources predict burnout, work engagement, and sickness absenteeism. J Organ Behav. 2009;30(7):893-917 (DOI: 10.1002/ job.595).

42. Elovainio M, Kivimäki M, Vahtera J. Organizational justice: evidence of a new psychosocial predictor of health. Am J Public Health. 2002;92:105-8.

43. Siu O-L, Spector PE, Cooper GL, Donald I. Age differences in coping and locus of control: a study of managerial stress in Hong Kong. Psychol Aging. 2001;16(4): 707-10.

44. de Jonge J, Bosma H, Peter R, Siegrist H. Job strain, effort-reward imbalance and employee well-being: a large-scale cross- 
sectional study. Soc Sci Med. 2000;50(9): 1317-27.

45. Ministry of Social Affairs and Health [of Finland]. Occupational safety and health act (No. 738/2002). Retrieved unofficial translation September 20, 2010, from: http://www.finlex.fi/en/laki/ kaannokset/2002/en20020738

46. Mäkitalo J. Work-related well-being in the transformation of nursing home work [academic dissertation]. Oulu, Finland: University of Oulu; 2005.

47. Diener E, Lucas RE. Personality and subjective well-being. In: Kahneman D, Diener E, Schwarz N, editors. Well-being: the foundations of hedonic psychology. New York, NY, USA: Russel Sage Foundation; 2003. p. 213-29.

48. Peto V, Jenkinson C, Fitzpatrick R, Greenhall. R. The development and validation of a short measure of functioning and well being for individuals with Parkinson's disease. Qual Life Res. 1995; 4(3):241-8.

49. Hayes BE, Perander J, Smecko T, Trask J. Measuring perceptions of workplace safety: development and validation of the work safety scale. J Safety Res. 1998;29(3): 145-61.

50. Tuomi K, Vanhala S, Nykyri E, Janhonen M. Organizational practices, work demands and the well-being of employees: a follow-up study in the metal industry and retail trade. Occup Med (Chic Ill). 2004;54:115-21.

51. Flin R, Mearns K, O'Connor P, Bryden R. Measuring safety climate: identifying the common features. Saf Sci. 2000;34:177-92.

52. Zohar D. Safety climate in industrial organizations: theoretical and applied implications. J App Psychol. 1980;65(1): 96-102.

53. Andersson K. Epidemiological approach to indoor air problems. Indoor Air. 1998;8(S4):32-9 (DOI: 10.1111/j.16000668.1998.tb00005.x).

54. Reijula K, Sundman-Digert C. Assessment of indoor air problems at work with a questionnaire. Occup Environ Med. 2004; 61:33-8.

55. Nygård C-H, Huuhtanen $\mathrm{P}$, Tuomi K, Martikainen R. Perceived work changes between 1981 and 1992 among aging workers. Scand J Work Environ Health. 1997;23 Suppl 1:12-9.

56. Mäkikangas A, Feldt T, Kinnunen U. Psykologiset kyselymenetelmät ja niiden käyttö työelämässä [Psychological questionnaires and their use in the working life]. In: Aro A, Feldt T, Ruohomäki V, editors. TOP 1: Puheenvuoroja työ- ja organisaatiopsykologiasta [Statements of work and organizational psychology]. Helsinki, Finland: Edita; 2007. p. 30-58. 